\title{
RESPONSIBILITY OF PERSONALITY IN COORDINATES OF PSYCHOLOGICAL ANALYSIS
}

\author{
Arsen LYPKA
}

УАK 159.922

\section{Арсен $\Lambda$ ика \\ ВІДПОВІДАЛЬНІСТЬ ОСОБИСТОСТІ \\ В КООРДИНАТАХ ПСИХОЛОГІЧНОГО АНАЛІЗУ}

\author{
"... Freedom is the will to personal responsibility" \\ (F. Nietzsche) \\ "... The ability to responsibility itself is a blessing" \\ (H. Jonas)
}

Setting a public problem. A person throughout his life faces a certain number of expectations and roles in the society associated with responsibility, as well as control over his or her own behavior, taking into account the influence of both the micro-environment and the corresponding social institutions. Anyway, social agents of the micro- meso- and macro level not only largely determine the models of responsible behavior of the person, but also stimulate the formation of her expectations and actualize her humane potential.

Analysis of recent researches on the raised problem. The theoretical-analytical format of the proposed exploration is substantially based on the concepts of: the psychological responsibility of K. Muzdybayev [5], responsible behavior of M. V. Savchyn [9-11], personal responsibility of O.Y. Furman (Humeniuk) [18].

Singling out of previously unsolved parts of the general problem to which the article is devoted. The research for the first time analyzes the formation of the phenomenon of personal responsibility through the processes of socialization and personalization, a group of determination factors, which in the complementarity actualize the emergence of a four-component structure of responsibility and make it possible to identify the important components of the canon of the person responsibility. In addition, for the first time, an addition is proposed in the title and substantiation of the first component of responsibility - "mental-cognitive".

Formulation of the article goals (setting tasks). The research substantiates: a) a time deployment of aspects of responsibility by S. L. Rubinstein; b) the influence of the processes of socialization, personalization and the four groups of determination factors (global, macro-, mesa, micro-factors) on the formation of personal responsibility of a person; c) psychological analysis of the four-component structure of personal responsibility and the discovery of differences between the external and internal types of responsibility.

Presentation of the main research material. Responsibility is, first of all, a serious person's attitude to life, which, on the one hand, contains an idea of its irreversibility, on the other - a situationally and subjectively caused specific deed of responsibility to everyday life, regarding to professional growth or moral choice. Hence, it is clear that responsibility is a socially acquired peculiarity of the personality, which manifests itself in its activities and, above all, in moral actions. In fact, each psychological phenomenon is an individually responsible deed, and from 
the set of deeds a human's life is formed. A significant feature of the committing is responsibility. For example, M. M. Bakhtin believes that the responsibility of the deed is to take into account all factors in it: both semantic significance and real committing [1].

The problem of multilevel personal responsibility for today is a reflection of the complex organization of the social interaction of the subject in society $[\mathbf{1 1} ; \mathbf{1 7} ; \mathbf{1 8}]$. In this case, the socio-psychological determinants create certain preconditions, on the basis of which there is a responsibility or irresponsibility as a personality characteristic of human and a specific level of its developmental functioning is determined. In addition, the determinants of a purely environmental-situational nature, which contribute or hinder the appearance of actually person's conscious personal responsibility in the everyday life of his inner world or in social life, acquire significant weight.

Let's note that responsible behavior of personality is different in its requirements, motives and sanctions in various socio-cultural and political systems. Thus, under conditions of democracy and totalitarianism, it is formed and controlled by the excellent means and methods, motives and forms of encouragement; in the end, there are various resulting vectors of good faith - either the affirmation of human dignity or humiliation of the personality.

It is clear that social life as a kind of social has a relative self-sufficiency and is determined by the completeness of freedoms and the existence of the rights of the person, their respective guarantees from the state, such as, for example, social protection or the system of social providing. At the same time, sociality also means the development of human responsibility towards society, the state, the team, and the family. Therefore, the social everyday life forms the foundation of the social culture of society and a particular person, in particular, the quintessence of which is the responsibility for others, first of all for family and friends [17].

In general, the term "responsibility" has two interrelated meanings: responsibility "for" something or someone and responsibility "before" someone. The first one foresees taken by man obligations for his own actions, the consequences of his activity, the responsibility for someone, for the sake of something; the second one - before someone - with relatives, other people, society, God. For H. Jonas responsibility "for" is more important than the responsibility "before" $[\mathbf{4}, \mathbf{p .} \mathbf{3 8 3}]$, because its archetype is a deep where is intersection of being, affiliation and freedom. Therefore, responsibility is caused, on the one hand, by a formal law (as an external obligation), and, on the other hand, by deep (internal) self-attitude to the case, to oneself, to people, and, eventually, to life.

In this regard, S. L. Rubinstein argues that there is a temporal disclosure of the phenomenon of responsibility: a) the responsibility for the action - a retrospective aspect; b) the responsibility for what is needed to be done - a perspective aspect; c) the responsibility "here and now" or for this particular moment of life - the contemporary aspect $[\mathbf{7} ; \mathbf{8}]$. The last one will be denoted as existential, which is consonant specifically with the responsibility "for" where the completeness of existence in the present dimension is present. Of course, the responsibility of mankind for its present and temporarily distant future is reflected not only on it but also on the younger generation. Therefore, "what it will be harmonious, stable, with a high level of provision or, conversely, aggressive-emotional - depends on the life position of each and those socio-economic processes that the people make it possible to take place in the state" $[\mathbf{1 8}, \mathbf{p . ~ 8 6}]$.

In this context, become important personal responsibility (what the specific individual has done) and the responsibility of society before it, because in it a person happens. Therefore, the person is responsible for "... people like it, that is, for those of whom the society is formed (and here it is necessary to take into account also what they have done for him) of the given moment, and, therefore, for the inherited a country of the contemporaries who have entrusted power to it. In addition, it transmits the received inheritance to the future " $[\mathbf{4 ,}$ p. 192]. Therefore, responsibility today is rightly considered both as a social phenomenon and personality trait of a person, and as an "important theoretical construct of modern psychology, which allows by the means of abstractionconstructivization to attribute a special independent status to the properties of social and cultural events, to life and psychological changes. In this case, responsibility is an abstract model, in the basis of creation of which is not an idealization procedure, but abstraction, schematization, typologization, and professional methodologization in general" $[\mathbf{1 6}, \mathbf{p . 7 9}$.

The foregoing gives an understanding of the fact that the responsibility of the personality is a conscious daily comparison of his own behavior 
with social norms and regulations, and not only with his installations as the consequences of intreriorized (external is transformed into internal, according to L. S. Vygotsky) influences. Hence, responsibility characterizes human relationships and relates to various aspects of human life activity, defines its orientation. It is manifested in consciousness, character, will, emotions, and in the behavior, activity and, at the same time, freedom of choice of personality.

According to the concept of M. V. Savchyn freedom is connected with responsibility, that is, with the choice of the external (in the world) and the internal (in his personality). Freedom foresees transcendence, the psychological mechanism of which is the process of finding an individual meaning of life, which arises in interaction, which does not allow one-sided subordination to the "external" and does not transform a person into a slave of their own needs, their direct situational interests $[\mathbf{9 ;} \mathbf{1 0} ; \mathbf{1 1}]$.

Of course, responsibility is psychological category, since it always reflects the degree of conformity of actions of social subjects with mutual requirements, as well as specific historical norms and general interests of their everyday life. This conformity is caused by the regularities of the joint residence of people, the need to mutual subordinate their goals and actions, in connection with which each person acts as an active carrier of certain social obligations (statuses, roles, functions, vocations, etc.) [3, p. 106-107].

So, we note that socialization provides adaptation or accommodation of a person to society, and personalization - the adaptation of society to it, where a particular common denominator is its conscience, obligatoriness. Through these processes, the cultural heritage of society in the psycho-spiritual world of man, its responsibility before him and, in fact, his life, is actualized.

By the nature of the emergence of the responsibility phenomenon at the personal level of psychogenesis through the process of socialization, the following components of responsibility, such as knowledge, normative, motivational, emotional, cognitive, are actualized. At the same time personification finds expression in another set of components: value-semantic, moral, motivational-active, volitional, reflexive. The dialectics of multi-component interpenetration of these system-creating processes ultimately determines the integrity and degree of development of personal responsibility of a person as an integral psycho-spiritual characteristic-quality of his individual world of "I".
Thus, the stimulatory-developmental influence of the complex structural processes of socialization and personalization on the formation of the responsibility of the personality as its synthetic (integral) trait and at the same time the way of relation / attitude towards the world, other people and itself determines the emergence of important mental formations moral convictions, social instructions and stereotypes (influences of the social environment), installations (self-influences as consequences of instructions), cognitive schemes and self-concept as the central link of self-consciousness [13].

Taking into account the above, there are grounds for singling out at least four groups of determinative factors of personal responsibility: global (civilized or common-human); macro- at the level of separate countries, regions; meso- available in the space of organizations, labor, educational or other groups; micro-factors, that is, those that are found at the level of medium and small groups and a specific person.

The mutually-caused action of these various scale factors on the personality, their one or another refraction through the internal conditions of development, respectively, intensively forms on the stages of childhood and adolescence situationally and individually responsible, irresponsible behavior in society as an important dimension-parameter of its psycho-social maturity. Moreover, a favorable complementarity of these factors develops the responsibility of the personality not so much as an imperative, a norm, a duty, but as a tendency for productive behavior, as a strategy of good faith in work, as a style and way of a skillfully filled life with useful things. Such a responsibility by an intention and psycho-spiritual content, undoubtedly, is the source and driving force of internally motivated, responsible actions and deeds of the personality, which, on its part, helps to systematize its mental social and spiritual experience, is an important mechanism of psycho-regulation of behavior and activity and at the same time the core of arrangement the value-sense sphere and the harmonization of the self-concept.

In any case, stated facts and arguments indicate that responsibility in modern society plays an extremely important role in the development of personality. One of the most important characteristics of the personality is independence and moderate activity in achieving its goals, center around personal responsibility for the events that happened with her, for the content of her own live. If a person is responsi- 
ble, then this is, of course, a decisive feature of her psycho-social maturity, availability of the desire to continuously improve her and establish interpersonal relationships.

However, responsibility is caused and manifested in society in different ways, in particular in the internals and externals. It is known that the theory of $J$. Rotter [20] investigates the psychic phenomenon of internality, which is opposed to externality. So, if a person is inclined to address responsibility for all to external factors, to find the reasons in others, then this indicates on the presence of externality. Internals do not relinquish the obligation and do not delegate it to others, they are responsible for all events. In other words, in the first case, the results of behavior are under the control of external conditions and circumstances, and in the second one - the internal. However, the more common is the mixed type of personality, singled out as a certain ratio of two of these experiments.

The above mentioned gives grounds to to assert that internals are individuals oriented towards the future, because they live internally "here and now", and therefore more responsible, and externals - retrospective individuals, since they focus on past events, which makes them more external. In general, the responsible person does not return to the past, but lives in fullpower in the "present". Of course, internals understand that almost all important events of their own lives are the result of their actions, so responsible for them and for how their lives proceed. They believe that they themselves have achieved everything that was and is available in their lives, and therefore in the future they can achieve their goals. Moreover, they also take responsibility for negative events, tend to blame themselves for failures, suffering and etc., responsible for family life, complaining not about a partner, but on themselves. Thus, the personalities of the internal style of behavior are characterized by an active position in life, independence and responsibility for themselves. The externalities, on the contrary, are mostly passive, they feel insignificance (that is, they believe that nothing depends on them), therefore, they are separated from life, and their own successes, achievements and joys do not feel as their own (preferring external circumstances), luck and help from others. In other words, the people of the internal type - the winners, and the external - are defeated.

According to K. Muzdibayev, responsibility is "the result of the integration of all mental functions of the personality: the subjective perception of the world, the assessment of their own sensory resources, emotional attitude to duty, will" [5; 11, p. 7]. It is also a semantic personality formation and, at the same time, the general principle of correlation (personal self-regulation) of motives, goals and means of life activity that is not limited to a rule or codex of behavior, is not a specific motive or their totality $[\mathbf{1 1}, \mathbf{p .} \mathbf{6}]$. Hence, responsibility is an integral personal formation, which is effectively mutually caused by external and internal structures.

The first one includes: a) the subject (who answers), b) the object (for what is responsible) and c) the authority (to who is responsible). In the role of the subject can be a person, a team, a large or a global community, whose individual, group or mass activity is subject to evaluation. The subject is responsible for the object, that is, what is laid upon him or accepted by him for execution. Here it is spoken of a public expression of will, expressed in the form of social norms and role functions, as well as the tendency of a person to realize the source of leadership of his life, mainly in the external environment or vice versa in himself $[\mathbf{1 2}$, p. 50-51].

At the same time, the internal detection of the structure of responsibility is organized by the components known in psychology, which cover the quaternary structure and form the unity of "cognitive, emotional-motivational, behavioral-volitional" $[5 ; 9 ; 11]$ and "moralspiritual" [18] components.

In this regard M. V. Savchyn analyzing the above mentioned components of the responsibility structure, considers that cognitive includes the following elements: 1) "awareness by the personality of the subject of responsibility, which is inseparably linked with moral consciousness and self-consciousness; 2) the authority of responsibility (foresees the perception by the personality a role and capabilities of individuals or groups to control, stimulate and evaluate its behavior; the presence of experience in interacting with the authority, etc.); 3) assessing oneself as the subject of responsible behavior ...; 4) self-regulatory function (characteristic of social memory and thinking, ability to creativity in the analysis of behavior, cognitive style of solving problems, etc.) " $[\mathbf{9}$, p. 26].

The emotional-motivational component, as the author [9] rightly points out, is manifested in the corresponding mental states, experiences, 
1 - mental-cognitive: cultural

heritage of the people

(traditions, ideals, beliefs, mental installations, customs, etc.), social memory, thinking, perception, cognitive style of problem solving, conviction, etc.
4 - moral-spiritual: a source of spiritual-sense states emergence - the depths of the inner self; form of selfcreation, self-comprehension which foresees self-realization of a human as an authentic person, the basis for actualization of the faith, honor, truth, mercy, etc., where conscience is the main regulator of commission and afteraction; emergence of spiritual neoplasm (ideas, formations and etc.) (according to O. Y. Furman)

3 - behavioral-volitional: a set of actions, deeds, thanks to which in external or internal sense a person implements a subject of responsibility or selects means of this behavioral and action implementation (according to $\mathrm{M}$.

V. Savchyn)

norms, principles, needs,

interests, readiness for a certain

line of behavior (according to M.

V. Savchyn)

Fig. 1.

Psychological structure of personal responsibility

feelings that arise under the influence of a certain attitude towards accepted in the microenvironment ethical norms, principles, needs, interests, readiness for action, and holds the totality of motives of the person, which prompts the implementation of the conceived. With the help of the motivation process, the motives are actualized, the purpose and readiness of the person to act, to choose his means and methods, arises. So, in the motivational cycle, its various needs, motives, worldview orientations, emotional-value formations and demands are involved.

The behavioral-volitional component of responsibility keeps a system of actions, deeds that allow a person "to realize the subject of responsibility"; "in the external sense it is manifested through the fulfillment of duties, requirements, obligations, tasks, etc., and in the internal - when making decisions, when selecting and assessing the means of realization of the responsibility subject, self-analysis of behavior and his "Self", taking positions concerning events, other people, groups and himself, at last when developing the self-development program of "Self", etc. " $[\mathbf{9}, \mathbf{p .} \mathbf{2 8}, \mathbf{2 9}]$.
O.Y. Furman (Humeniuk) by singling out the fourth component in the structure of responsibility - moral-spiritual, notices that it is organized by several levels: a) acts as a product of vital activity, which enriches experience; $b$ ) is the source of the emergence of spiritual-sensory states - the depths of the inner Self; c) is organized as a psycho-form of the self-development, which foresees the self-realization of personality as a universum [18].

Analyzing the structural structure of the responsibility phenomenon, we believe that the first component - cognitive - should be combined with the mental, where archaic experience is preserved. In this regard, we offer to call "mentally cognitive" (fig. 1). Such integration, on the one hand, is connected and is purely logical, since all other components have a double formation (e.g., "emotionalmotivational", "behavioral-volitional", and "moral-spiritual"). On the other hand, by resorting to the analytical approach of K.G. Jung, in the structure of the personality, apart from Ego as the center of the sphere of consciousness and personal unconscious (suppressed 


\section{1 - mental-cognitive component: prevails duty, benefit}

4 - moral-spiritual component: based on freedom, reflection,

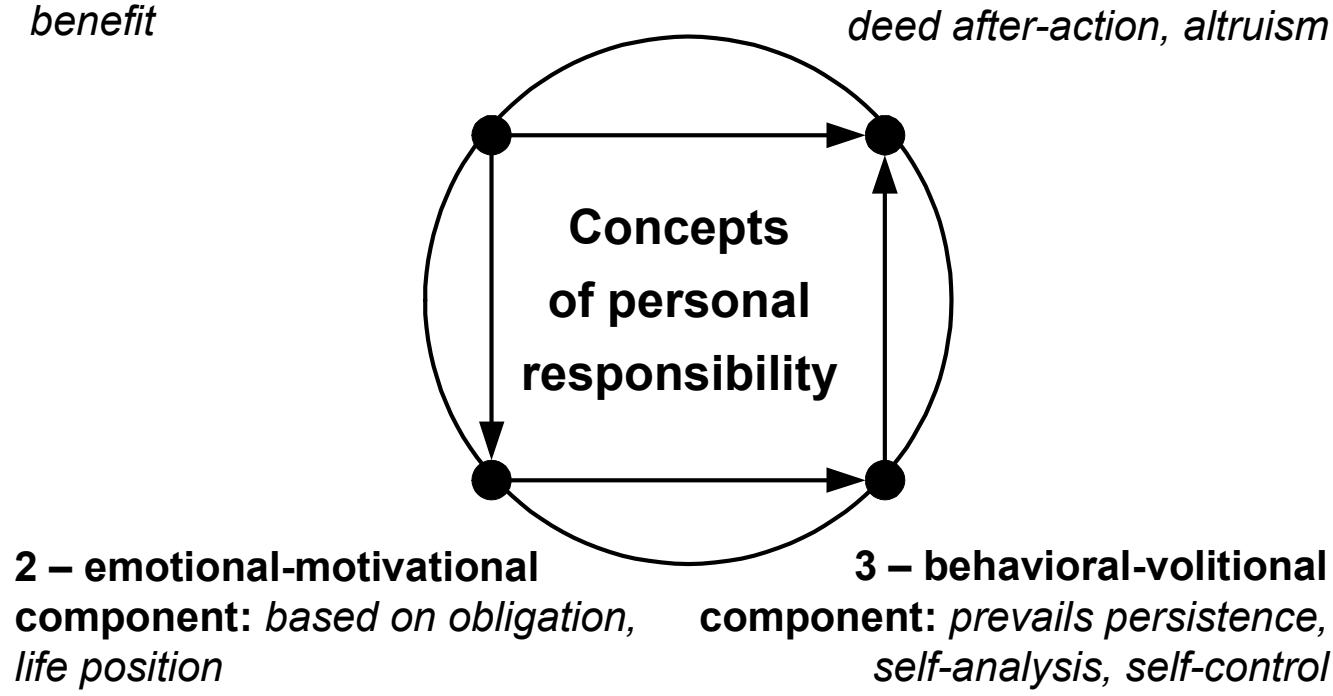

Fig. 2.

\section{Conceptual delimitation of structural components of personal responsibility}

conflicts), is perhaps the deepest layer of the psyche - the collective unconscious, in which, in the form of archetypes, or primary mental images ("person", "shadow" , "Self", "sage", etc.), all spiritual heritage of human evolution is kept - traces of emotions and memory, thoughts and experiences [19]. As O.A. Donchenko notices, “one of Jung's extreme guesses is the recognition that we are born not only with biological but also with the psychic heredity that determines our behavior and experience. Therefore, the collective unconscious holds up the psychic material, which does not arise in personal experience ..., it is like air, which breathes everyone and which does not belong to anyone " $[\mathbf{2}, \mathbf{p .} \mathbf{1 5}]$.

From the point of view of scientists, the world of mentality in its essence has an intersubjective character [15]. And this means that it holds a large number of mental processes, formations and mechanisms that are realized and rationalized in part and fragmentarily. Hence, "very complex structural organization of the psycho-social content of mentality that dynamically combining in the removed form the opposition characteristics of human life and activity - natural and cultural, emotional and rational, unconscious and conscious, individual and social, unique and universal, instinctive and spiritual" $[15$, p. 41].
At the same time, mentality is also a sociopsychological self-organization of representatives of a certain cultural tradition [15] characterized by the unity of their attitudes, experiences, thoughts, feelings and manifested in the identity of world perception and worldview, determines the level of mental-cognitive consciousness and self-consciousness.

The substantiated psychological structure of personal responsibility makes it possible to single out the main categories and concepts according to the differentiated components (fig. 2), although the last ones are interconnected and form a single whole in the real world of the human.

In the works of humanistic psychologists (C. Rogers and other) the following personality features of full-functionality are defined, which characterize the behavior of the internals to a greater extent and constitute important components of the canon of the responsible person:

a) self improvement of the personality - it is openness to the latest experiences, when it is able to listen to itself, to feel the whole spectrum of emotional and cognitive experiences; then clearly understands its deepest thoughts and feelings without trying to simplify or dampen them;

b) an existential way of life, and therefore a specific being on the principle "here and now", when a person deeply feels, experiences and 
spiritually fills every moment of its own vital activity and knows the joy of social interactions;

c) organismic trust, which is most pronounced when making decisions; such people never live for the sake of social traditions and norms, but, professing them, they use for their own cultural development and self-improvement;

d) empirical freedom preaching life without internal limitations and prohibitions, when the subjective understanding of freedom is the ability to personally rule over the situational being, on the basis of own experience and knowledge, to make a choice of strategies, principles, methods, means and techniques of life activity;

e) optimization of activity and attraction to self-improvement - creativity, that is creative potential of the person; at this the creative way of life in general is inherent in people with a mature life position, who seeks to be implemented constructively and perfectly, to defend their claims by flexible adaptation to changeable environmental conditions, which is a higher degree of responsibility from the above-mentioned features (see [6]).

\section{CONCLUSIONS AND PERSPECTIVES OF FURTHER RESEARCHES}

1. Responsibility - is a very complex psychosocial phenomenon, which permeates all spheres of human life - from personal to economic and even political. At the same time, responsibility is worldview universals, aimed at a person and is its highest moral value.

2. Phenomenologically, responsibility has external structure (object, subject and authority) and internal (mental-cognitive, emotionalmotivational, behavioral-volitional, moralspiritual components). The indicated structure combines the subject of responsibility, which in content and volume covers its specific duties, tasks, orders, methods of their implementation, observance of certain norms or avoidance of individual actions, moral ideal and deeds of liferealization, and hence freedom of choice.

3. The structural components of responsibility are theoretically delimited, and in the real life of a person they form a single entity, mutuallycaused, mutually crossed with each other and provide stability to its behavior, activity and actions.

4. Perspective directions of further research of this theme are a scientific analysis of the available theoretical concepts of responsibility of the personality in domestic and foreign psychology.

\section{LITERATURE}

1. Бахтин М.M. Вопросы литературы и эстетики: Исследования разных лет / Михаил Михайлович Бахтин. - М.: Худож. л-ра, 1975. - 504 с.

2. Донченко Е.А. Социетальная психика / Е.А. Донченко. - К.: Наукова думка, 1994. - 208 с.

3. Енциклопедія освіти / Акад. пед. наук України; гол. ред. В.Г. Кремень. - К. : Юрінком Інтер, 2008. - 1040 с.

4. Йонас Г. Принцип відповідальності. У пошуках етики для технологічної цивілізації / Г. Йонас; пер. 3 нім. - К.: Лібра, 2001. - 400 с.

5. Муздыбаев К. Психология ответственности / К. Муздыбаєв. - Л.: Наука, 1983. - 240 с.

6. Роджерс К.Р. Взгляд на психотерапию. Становление человека / Карл Роджерс; пер. с англ. [общ. ред. и предисл. Исениной Е.И.]. - М.: Изд. группа "Прогресс", "Универс", 1994. - 480 с.

7. Рубинштейн С.Л. Бытие и сознание. Человек и мир / Сергей Леонидович Рубинштейн. - СПб.: Питер, 2003. - 512 с. - (Серия "Мастера психологии").

8. Рубинштейн С.Л. Основы общей психологии / Сергей Леонидович Рубинштейн. - СПб. : Питер, 2000. - 712 с.

9. Савчин М.В. Психологія відповідальної поведінки / М.В. Савчин. - К: Україна-Віта, 1996. -130 с.

10. Савчин М. Свобода і відповідальність особистості / Мирослав Савчин // Психологія і суспільство. 2007. - №4. - С. 73-80.

11. Савчин М.В. Психологія відповідальної поведінки : [монографія] / М.В. Савчин. - Івано-Франківськ: Місто НB, 2008. - $280 \mathrm{c}$.

12. Третьяченко В.В., Баранова С.В., Бочонкова Ю.О., Тереніна Л.В. та ін. Психологічна культура особистості в умовах глобалізації світу : [монографія] / за заг. ред. Третьяченко В.В. - Луганськ: Світлиця, 2006. - 352 с.

13. Фурман (Гуменюк) О.С. Психологія Я-концепції: навч. пос. / О.Є. Фурман (Гуменюк). - Тернопіль: Економічна думка, 2004. -310 с.

14. Фурман (Гуменюк) O.С. Теорія і методологія інноваційно-психологічного клімату загальноосвітнього закладу : [монографія] / О.Є. Фурман (Гуменюк). - Ялта-Тернопіль: Підручники і посібники, 2008. - 340 с.

15. Фурман A.В. Психокультура української ментальності / А.В. Фурман. - Тернопіль: Економічна думка, 2002. - 132 с.

16. Фурман A.B. Ідея професійного методологування : [монографія] / Анатолій В. Фурман. - Ялта-Тернопіль: Економічна думка, 2008. - 205 с.

17. Фурман A.B. Соціальна культура / Анатолій В. Фурман, Олена Морщакова // Психологія і суспільство. - 2015. - № 1. - С. 26-36.

18. Фурман O.С. Громадянська відповідальність особистості як предмет психологічного дослідження / О.Є. Фурман // Психологія і суспільство. - 2015. - №1 . - C. $65-91$.

19. Юнг К.Г. Проблемы души нашего времени / Карл Густав Юнг; пер. с нем. - М.: Прогресс, 1993. - 310 с.

20. Rotter J.B. Some problems and misconceptions related to the construct of internal versus external control of reinforcement // Journal of Consulting and Clinical Psychology. - 1975. - №43. - P. 56-67. 


\section{REFERENCES}

1. Bahtin M. M. Voprosy literatury i estetiki: Issledovaniya raznyh let / Michail Michaylovich Bahtin. - M.: Hudozh. Lra, 1975. $-504 \mathrm{~s}$.

2. Donchenko E. A. Sotsietalnaya psihika / E. A. Donchenko. - K.: Naukova dumka, 1994. -208 s.

3. Entsyklopediya osvity / Akad. ped. nauk. Ukrainy; hol. red. V. H. Kremen'. - K.; Yurinkom Inter, 2008. - $1040 \mathrm{~s}$.

4. Yonas H. Pryntsyp vidpovidal'nosti. U poshukah etyky dlya tehnolohichnoi tsyvilizatsii / H. Yonas; per. $\mathrm{z}$ nim. - K.: Libra, 2001. - 400 s.

5. Muzdybaev K. Psiholohiya otvetstvennosti / K. Muzdybaev. - L.: Nauka, 1983. - $240 \mathrm{~s}$.

6. Rodgers K. R. Vzglyad na psihoterapiyu. Stanovlenie cheloveka/KarlRodgers; per.sanhl. [obshch. red.ipredisl. Iseninoy E. I.]. M.: Izd. Gruppa "Progress", "Univers", 1994. - 480 s.

7. Rubinshteyn S. L. Bytie i soznanie. Chelovek i mir / Sergey Leonidovich Rubinshteyn. - SPb.: Piter, 2003. 512 s. - (Seriya "Mastera psiholohii").

8. Rubinshteyn S. L. Osnovy obshchey psiholohii / Sergey Leonidovich Rubinshteyn. - SPb.: Piter, 2000. - $712 \mathrm{~s}$.

9. Savchyn M. V. Psyholohiya vidpovidal'nosti povedinky / M. V. Savchyn. - K.: Ukraina-Vita, 1996. - 130 s.

10. Savchyn M. V. Svoboda i vidpovidal'nist' osobystosti / Myroslav Savchyn // Psyholohiya i suspil'stvo. - 2007. №4. $-\mathrm{S} .73-80$.

11. Savchyn M. V. Psyholohiya vidpovidal'noi povedinky :[monohrafiya]/M. V. Savchyn. - Ivano-Frankivs'k: Misto $\mathrm{NV}, 2008 .-280 \mathrm{~s}$.

12. Tret'yachenko V. V., Baranova S. V., Bochonkova Yu. O., Terenina L. V. ta in. Psyholohichna kul'tura osobystosti v umovah hlobalizatsii svitu: Monohrafiya / Za zah. red. Tret'yachenko V. V. - Luhans'k: Svitlytsya, 2006. - 352 s.

13. Furman (Humeniyk) O. Ye. Psyholohiya Yakontseptsii: navch. pos. / O. Ye. Furman (Humeniyk). Ternopil: Ekonomichna dumka, 2004. - $310 \mathrm{~s}$.

14. Furman (Humeniyk) O. Ye. Teoriya i metodolohiya innovatsiyno-psyholohichnoho klimatu zahal'noosvitn'oho zakladu : [monohrafiya] / O. Ye. Furman (Humeniyk). Yalta-Ternopil: Pidruchnyky i posibnyky, 2008. - 340 s.

15. Furman A. V.Psyhokul'tura ukrains'koimental'nosti/A.

V. Furman. - Ternopil: Ekonomichna dumka, 2002. - $132 \mathrm{~s}$.

16. Furman A. V. Ideya profesiynoho metodolohuvannya: [monohrafiya] / Anatoliy V/ Furman. - YaltaTernopil: Ekonomichna dumka, 2008. - 205 s.

17. Furman A. V. Sotsial'na kul'tura / Anatoliy V. Furman, Olena Morshchakova // Psyholohiya i suspil'stvo. - 2015. - №1. - S. 26 - 36.

18. Furman O. Ye. Hromadyans'ka vidpovidal'nist' osobystosti yak predmet psyholohichnoho doslidgennya/O. Ye. Furman/ / Psyholohiya i suspil'stvo. - 2015. - №1. - S. 65 -91.

19. Yunh K. G. Problemy dushu nasheho vremeni / Karl Gustav Yung; per. s nem. - M.: Progress, 1993. - 310 s.

20. Rotter J.B . Some problems and misconceptions related to the construct of internal versus external control of reinforcement // Journal of Consulting and Clinical Psychology. - 1975. - №43. - P. 56-67.

\section{АНОТАЦІя}

\section{Липка Арсен Олегович.}

Відповідальність особистості в координатах психологічного аналізу.

Відповідальність - це надскладне психосоціальне явище, котре пронизує всі сфери життя людини - від особистої до економічної і навіть до політичної. Тому в роботі ії розглянуто як суспільний феномен та як особистісну рису й водночас як важливий теоретичний конструкт сучасної психології, що дає змогу приписувати особливий самостійний статус властивостям соціальних і культурних подій, життєвим і психологічним змінам. Проаналізовано становлення феномену особистісної відповідальності через процеси соціалізації й персоналізації, виокремлено групи детермінаційних чинників, котрі у взаємодоповненні актуалізують виникнення чотирикомпонентної структури відповідальності та уможливлюють визначення важливих складників канону персональної відповідальності. Висвітлено спричинення та виявлення відповідальності у суспільному повсякденні людей, зокрема в екстерналів та інтерналів. Доведено, що інтернали, будучи зорієнтовані в майбутне, живуть внутрішньо “тут і тепер", а тому більш особистісно відповідальні, тоді як екстернали, обстоюючи ретроспективні інтенції, зосереджені на минулих подіях, що у світосприйнятті відкидає їх у минуле. Воднораз виокремлено чотири групи детермінаційних чинників особистісної відповідальності: глобальні (цивілізаційні або загальнолюдські); макро- - на рівні окремих країн, регіонів; мезо-унаявлені у просторі організацій, трудових, освітніх чи інших колективів; мікрочинники, тобто ті, що виявляються на рівні середніх і малих груп та конкретної особистості. На основі аналізу структурної побудови феномену відповідальності запропоновано перший компонент - когнітивний - поєднати із ментальним, у якому, крім інтелектуального потенціалу, збережений також архетипний досвід. У зв'язку з цим запропоновано назвати його "ментально-когнітивний".

Ключові слова: особистість, відповідальність, екстернал, інтернал, соціалізація; ментально-когнітивний, емоційно-мотиваційний, поведінково-вольовий, морально-духовний компоненти відповідальності, феноменологічний аналіз.

\section{ANNOTATION}

\section{Lypka Arsen. \\ Responsibility of personality in coordinates of psy- chological analysis.}

Responsibility - is a very complex psychosocial phenomenon, which permeates all spheres of human life - from personal to economic and even political. Therefore, the work considers it as a social phenomenon and as a personal trait and at the same time as an important theoretical construct of modern psychology, which enables to attribute a special independent status to the properties of social and cultural events, life and psychological changes. Has been analyzed the formation of the phenomenon of personal responsibility through the processes of socialization and personalization, has been singled out a group of 
determination factors, which in the complementarity actualize the emergence of a four-component structure of responsibility and make it possible to identify the important components of the canon of the person responsibility. The article deals with causing and revealing of responsibility in the public everyday life, in particular in externals and internal ones. It has been proved that the internals, being oriented towards the future, live internally "here and now", and therefore more personally responsible, and the externals, defending retrospective intentions, focusing on past events, which in the world perception rejects them to the past. At the same time it was singled out four groups of determinative factors of personal responsibility: global (civilized or common-human); macro- - at the level of separate countries, regions; meso- - available in the space of organizations, labor, educational or other groups; microfactors, that is, those that are found at the level of medium and small groups and a specific person. On the basis of the analysis of the structural construction of the responsibility phenomenon, it was offered the first component - cognitive - to combine with the mental one, in which, in addition to the intellectual potential, also is preserved the archaic experience. In this regard, it is proposed to call it "mentallycognitive".

Key words: personality, responsibility, external, internal, socialization, mentally-cognitive, emotional-motivational, behavioral-volitional, moral-spiritual components of responsibility, phenomenological analysis.

Рецензенти:

д. психол. н., проф. Карпенко З.С., д. психол. н., проф. Савчин М.В.

Надійшла до редакції 03.05.2018. Підписана до друку 21.05.2018.

\section{Бібліографічний опис для цитування: \\ Lypka A. Responsibility of personality in coordinates of psychological analysis / Arsen Lypka // Психологія і суспільство. - 2018. - №1-2. - С. 109-117.}

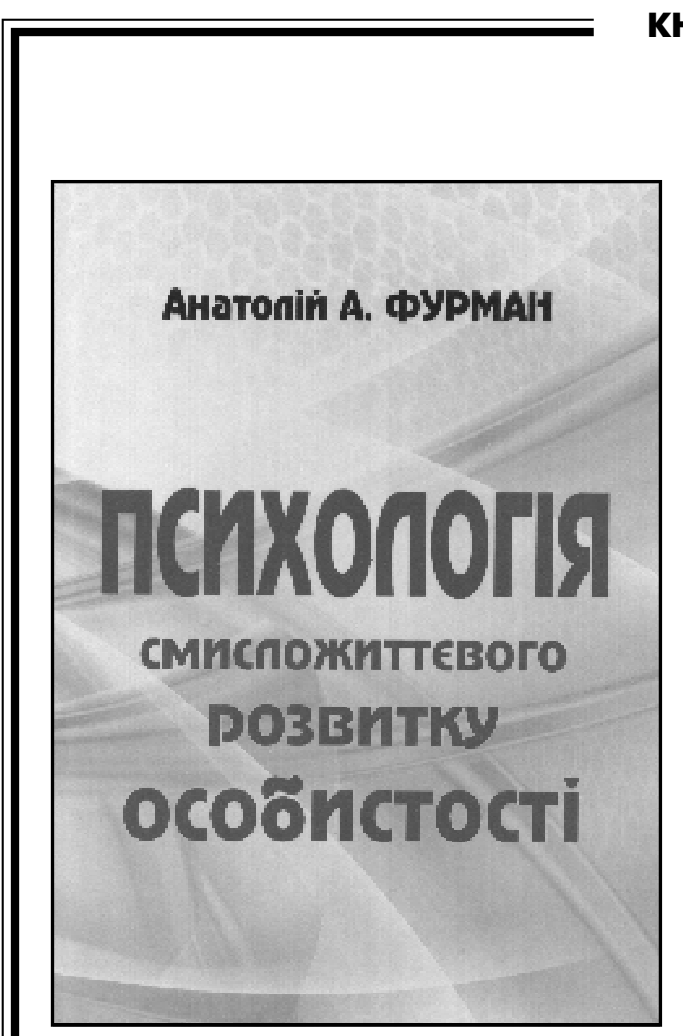

\section{КНИЖКОВА ПОЛИЦЯ}

Фурман А.А.

Психологія смисложиттевого розвитку особистості: [монографія] / Анатолій Анатолійович Фурман. - Тернопіль: THEУ, 2017. - 508 с.

Монографію присвячено теоретико-методологічному обгрунтуванню смисложиттєвої сфери особистості як системи свідомісних організованостей життеактивності, що впорядковує ії інтенційні та потенційні запити, засвідчує повномірне осягнення себе і дійсності, становить екзистенційне осереддя її персоніфікованого буття. Детально розглядаються вособистіснені смислоформи, що утворюють визначальний спосіб реалізації суб'єктом життєдіяльності свого покликання й упорядковують вітакультурний простір власного самоздійснення, стимулюють обрання унікального шляху-програми саморозгортання у ситуаціях буденності. Сенсосмисловий розвиток особистості витлумачується з позицій та інтелектуальних засобів компетентного методологування як закономірне розпросторення проблемно-модульної миследіяльності від актів поіменування та поцінування до діяльно-креативного і рефлексивного оволодіння нею навколишньою дійсністю й усвідомлення своєї присутності у світі та виходу на неозорі горизонти самотворення, що викристалізовується у вчинках осмислення буття й осенсовування життя.

Для дослідників загальнолюдських смислів і персоніфікованих сенсів як конституювального підгрунтя розвитку особистості, котра вдосконалюється в індивідуальному способі-вчиненні життєздійснення, заснованому на чіткому розумінні власних цінностей і цілей, пріоритетів і значень, які гармонізують ії̈ взаємостосунки з довкіллям у смисловій поліфонії соціокультурного повсякдення. 